\title{
Instructional Design of CALL Course in Indonesian Higher Education for Future English Teachers: A Case Study
}

\author{
Badi'atul Azmina ${ }^{1}$, Endang Fauziati ${ }^{2}$, Nur Arifah Drajati ${ }^{3}$
}

\section{ARTICLE INFO}

Article History:

Received 17.10.2018

Received in revised form

17.01.2019

Accepted

Available online 01.04.2019

\begin{abstract}
Along with the development of technology, the demand for sufficient preparation program of a future English teacher is increasing. This study aims to explore how the instructional design of Computer Assisted Language Learning (CALL) course in Indonesian higher education for future English Teachers. The focus of this study is on the syllabus implementation of CALL course including the objectives of the CALL course, the CALL materials, and classroom activities in CALL course. The setting of the research was in the English Education Department in one of Islamic University in Indonesia. It is qualitative research with case study design. The data collecting methods are document analysis, observation, and interview. The result revealed that specific syllabus was used in Computer Assisted Language Learning (CALL) preparation prog ram for future English Teachers. It covers of objectives of the CALL course, CALL materials, and CALL activities. The primary objective of the course is those future English teachers are expected to be able to do English teaching and learning using media and technology-based approach. It is reflected on the materials and the activities of CALL course. The materials include theories as well as practices of CALL. Further, the activities encourage future English teachers to review several applications and websites to be used in English teaching and learning, also, practice in designing CALL activities. The implication of this study is for example of designing Computer Assisted Language Learning (CALL) course for future English Teachers.
\end{abstract}

(C) IJERE. All rights reserved

Keywords:

Call, future eng lish teachers, higher education, instructional design, teacher preparation prog ram.

\section{INTRODUCTION}

The more digital natives the learners, the more language teachers need to employ information and communication technology (ICT) in their everyday teaching (Lee \& Lee, 2014). In order to prepare capable teachers who can integrate ICT well, the preparation program for future teachers is increasingly demanding. One of the technologies which can be applied to the English language teaching and learning is a computer or computer-assisted language learning. Furthermore, several universities in Indonesia have had CALL as a subject course for English Education or Literature students. Whereas, on how they prepare students, in this case, future English Teachers to teach CALL has not been explored yet.

Levy (1997) has defined Computer-assisted language learning (CALL) as "the search for and study of applications on the computer in language teaching and learning" (p.1). Papadima-Sophocleous (2012, p. 174) adds that "Computer-assisted language learning (CALL) is a field which has constantly been evolving since the early 60s, regarding both pedagogical changes and technological advances". Hashemi and Aziznezhad (2011, p. 833) propose that "CALL offers modern English language teachers many facilities and novel techniques for teaching and learning." Several advantages of CALL have been investigated such as encouraging autonomous learning and providing new teaching materials. Moreover, as explained by Ghasemi and Hashemi (2011, p. 3100), for language learning purposes, "it provides text in the authentic language, unlike the contrived language usually found in books." Furthermore, the CALL framew ork deals directly with integrating technology into language learning utilizing eight optimal conditions. According to Egbert and Hanson-Smith (1999), in the best CALL lessons, "learners (1) have opportunities to interact and decipher meaning, (2) interact in the target language with an authentic audience, (3) are involved in authentic tasks, (4) are exposed to, and encouraged to produce, varied and creative language, (5) are given enough time and feedback, (6) are helped to attend mindfully to the learning process, (7) work in an atmosphere with ideal stress levels, and (8) are allowed autonomy and supportive behavior" (p. 1-2).

To adjust to the development of technology, English teachers need to have the ability in integrating technology in the classroom. Queiroz (2003) insists on professional development, teachers, as well as

\footnotetext{
${ }^{1}$ Corresponding e-mail: cow.az19@gmail.com,/orcid.org/0000-0003-0650-7091, 2 orcid.org/0000-0001-8621-1412, 3 orcid.org/0000-0001-5828-5107 Universitas Sebelas Maret ${ }^{123}$
} 
Azmina,B., Fauziati,E.\& Drajati,N.A. (2019). Instructional design of CALL course in Indonesian higher education for future english teachers: A case study .International Journal of Educational Research Review, 4(2),223-230.

lecturers, have to improve their competency continuously. By doing this, their everyday practices are not just repetition. Then, the advantages of ICT development can be used. Therefore, ICT training for teachers should not be merely to use technology per se (Ghasemi \& Hashemi, 2011).

It is also important to prepare future language teachers in "incorporating the use of technologies, not only as part of their subject matter but also, very importantly, as part of their pedagogy and teacher training approaches" (Papadima-Sophocleous, 2012, p. 174-175). According to Katic (2008), "Preparing ... pre-service teachers to use technology in ways that transform learning practices is no easy task and one that falls on the shoulders of current teacher educators everywhere, regardless of content area discipline and technological proficiency" (p. 157). Katic (2008) furthers, "if teacher educators are to foster effective, progressive, and transformative uses of technology, they must first identify the conceptions that affect pre-service teachers' understandings and implementations of technology (p. 158).

Simon (2008) proposes that "adequate training is needed to help understand the pedagogy supporting the use of new technologies in language teaching and learning, and spread good practices to prepare graduate students for the needs of language teaching better. Technological skills and understanding how to employ new technologies to support pedagogy are vital for foreign language faculty today successfully". Further, Hashemi and Aziznezhad (2011) "the CALL classroom should not be conceived as a room in which every learner is studying in isolation in front of his/her computer. Teachers must think of activities that enable group work/human interaction and computers to be compatible" (p. 833).

Here, the instructional design of CALL courses is essential. Instructional design also called method design is the framew ork through which teachers take the planned learning and teaching actions to a lesson (Richards and Rodgers, 2003). Richards and Rodgers (2001) classify that the instructional design components are (a) specific objective, (b) a syllabus model, (c) classroom activities, (d) learners'role, (e) teachers' role, and (f) instructional materials. In this study, the focuses only on the learning objectives, instructional mater ials, and classroom activities.

McArdle (2010) argues that learning objective is a statement that tells what learners should be able to do when they have completed a segment of instruction. Another definition is from Soulsby (2009) that learning goals (i.e., learning objectives): “... brief, clear statements that describe the desired learning outcomes of instruction;i.e., the specific knowledge, skills, values, and attitudes students should exhibit that reflect the broader goals". Overall, the main objective of CALL is to "improve the learning capacity of those who are being taught a language through computerized means" (Cameron, 1999a, p. 2). While, Richards (2001, p. 251) defines that instructional materials generally serve as the basis for much of the language input learners receive and the language practice that occurs in the classroom. Then, CALL/internet activities include brow sing the internet, e-mailing, e-chatting, blogging, etc (Zhang, 2014).

Researches have been done on the study of CALL and CALL program for pre-service teachers. Lee, Y., \& Lee, J. (2014) investigates pre-service teachers' self-efficacy beliefs for technology integration through lesson planning practice. The results implied that "the CALL course was effective since the teachers' selfefficacy beliefs toward (for) technology integration significantly increased after their completion of the course mostly due to the lesson planning factor" (p. 126). Cordivari and Holland find out that education technology improves pre-service teachers' instructional practices. Also, the emphasis on essential computer skill mastery on the teacher preparation courses has been criticized by several researchers (Han, Eom \& Sug, 2013).

Although many studies have been conducted on the pre-service teacher preparation programs, this research seeks to find answers to the research questions: How is the instructional design of Computer Assisted Language Learning (CALL) course in Indonesian higher education for future English Teachers focusing on the syllabus implementation of CALL course including the objectives of the CALL course, the CALL materials, and classroom activities in CALL course?

\section{METHOD}

Stakes (1995) states that case study is the study of the particularity and complexity of a single case, coming to understand its activity within relevant circumstances. In the case study, the researcher explores in depth a program, an event, an activity, a process, or one or more individuals. Fauziati (2016) states that a 
case study focuses on the case, searches for an understanding, which pays attention to the uniqueness of individual case in its idiosyncrasy and its complexity. In this case, in Islamic State University where this study was conducted, Computer Assisted Language Learning (CALL) has become subject for English Education Department (Tadris Bahasa Inggris) students. The unique thing was that CALL becomes course subject for the first time this year, 2018. Also, students who have joined IMOOC (Indonesian Massive Open Online Course) had permission not to join the class. It was for 6th-semester students. It was elective subject. There are two classes of CALL and one lecturer who teaches them. These CALL subject are for all language skills including Grammar, Reading, Speaking, Writing, Listening, Pronunciation, Vocabulary teaching, Teaching with games, Comprehension, and Presentation skills.

In selecting the participants, researcher used purposive sample. It was used to find teacher who taught Computer Assisted Language Learning (CALL) Course. Only one teacher who met the requirement. The participants of this research are English lecturer of CALL and students (future English teachers) who joins the classes. As for the teacher, he is a male, 29 years old. He had his MA degree from The English and Foreign Languages (EFLU) University, India. He has become participant and facilitator/trainer in several technology-related programs such as Teacher Education Conference by British Council (participant), 15 Days Training on Skills for Presentation and Discussion (trainer), Indonesian Massive Open Online Course (participant then facilitator at iMOOC 2nd iteration), International Conference on English, Language, Linguistics and Education (ICELL): 'Digital Literacy as A Means of Publication' (presenter), etc. As for the students, three classes are consisting of 102 students, 32 male and 70 female. They are Javanese, 20-22 years old students form the same school, the Islamic State University. Meanwhile, the objects of this study are CALL course teaching and learning, especially the syllabus implementation including the objectives of the CALL course, the CALL materials, and classroom activities in a CALL course.

The data are the syllabus implementation including the objectives of the CALL course, the CALL materials, and classroom activities in a CALL course. They were collected by using interview, observation, and document analysis so that the data are in the form of interview notes, observation notes, and syllabus. This research used purposive sampling to find the university or faculty which has Computer Assisted Language Learning (CALL) subject course. To analyze the data, the researcher used interactive model data analysis proposed by Miles and Hubberman (1994) including data reduction, data display and conclusion drawing/verification.

\section{FINDINGS}

In this study, in order to prepare future English teachers to teach a language which integrates technology, especially Computer Assisted Language Learning (CALL), the university or faculty created CALL subject course for English Education Department students w how as currently at 6th semester. It is the elective subject of English Education Department. It is two point credits for them. It consists of 14 meetings. The course consists of three classes. The two of them were on every Tuesday, and the rest was on Wednesday. The course was conducted on a language laboratory. The specific syllabus was used in Computer Assisted Language Learning (CALL) preparation program for future English Teachers. It covers of objectives of the CALL course, CALL materials, and CALL activities.

\section{Objectives of the CALL Course}

The objective of this subject is that by attending CALL subject, university students are expected to do English teaching and learning using media and technology-based approach. Students need to (a) master technology-based English learning theories; (b) practice evaluating digital application media for language teaching and learning; also (c) design and present lesson plan using digital application media.

The lecturer himself developed those objectives because CALL course was held for the first time in that university. There was no established practice before in designing syllabus including the objectives of the course. He confessed that the CALL course was a trial one. He considered the students' need and background knowledge. Since the students did not get ICT-related subject before, teachers formulated the objectives that encourage them to do ICT-related activities.

Besides learning English using media and technology, in this course, students were practicing to do English teaching using technology. This means that to be able to teach English using ICT, students need to be 
introduced to them first. Then, by having experience in learning using ICT, they would figure out how to use ICT for teaching correctly. They would realize the struggle in learning using ICT, then find the advantages and disadvantages of specific ICTs. Later, they were expected not to do the same which produces disadvantages for their future students, and take the benefits of ICTs uses.

To have basic knowledge about technology-based English, thy need to learn about the theories first. This would shape their beliefs tow ard the use of technology in English teaching and learning. The beliefs later would be important for them as a guide to their actions of teaching practices using technology, especially CALL. Once, they had positive beliefs tow ard CALL, they would try to integrate CALL in their English teaching, and vice versa.

Then, having knowledge of theories of technology for English teaching and learning is not enough. The lecturer thought that as future English teachers, students need to have practice in analyzing several applications and websites for English teaching and learning. They need to explore the apps, then think of the features and affordances of the applications. Experiencing this activity encourage them to have images on how to use those features and affordances to teach English, whatever the skills are.

At last, students were expected to design and present lesson plan using digital application media. The lecturer realized that this objective is the toughest one. After students explore the apps, they need to practice designing a lesson plan using those apps. Besides considering the features, they need to consider the level of the students who will be taught. The availability of facility and connectivity are also important. All aspects of lesson plan also need to be considered including the learning objectives, classroom procedur es, materials, and assessment.

\section{CALL Materials}

The stated objectives are reflected on the materials of the CALL course. The materials include theories as well as practices of CALL.

Table 1. List of Topics in CALL Course

\begin{tabular}{|c|c|}
\hline $\begin{array}{c}\mathrm{M} \\
\text { eeting }\end{array}$ & Topics \\
\hline $\begin{array}{l}1 \\
2\end{array}$ & $\begin{array}{l}\text { 1. Learning Contract } \\
\text { 2. Introduction to Computer-Assisted Language Learning } \\
\text { From traditional to Computer-Assisted Language } \\
\text { Learning }\end{array}$ \\
\hline 3 & Living in the Technological Era/ Technological skills \\
\hline $4-5$ & Technology for autonomous learning: theory and practices \\
\hline $6-7$ & $\begin{array}{l}\text { Digital literacy: theory and practices } \\
\text { Mid-term Test }\end{array}$ \\
\hline $8-9$ & Researching and evaluating apps for English learning \\
\hline $10-11$ & Researching and evaluating sites for English teaching \\
\hline $12-14$ & $\begin{array}{l}\text { Apps/sites based lesson planning } \\
\text { Final Test }\end{array}$ \\
\hline
\end{tabular}

From Table 1, it can be said that there are two divisions of topics, theories, and practices. The theories consist of Introduction to Computer-Assisted Language Learning; From traditional to Computer-Assisted Language Learning; Living in the Technological Era/ Technological skills; Technology for autonomous learning: theory and practices; and Digital literacy:theory and practices. These are the implementation of the objective (a). Meanwhile, the practices consist of Researching and evaluating apps for English learning; and Researching and evaluating sites for English teaching. These are the implementation of the objective (b). The last topic is the implementation of the objective (c) that is apps/sites based lesson planning. 
Those materials can be from the references recommended by the lecturer.

Table 2. List of Reference in CALL Course

\begin{tabular}{|c|c|}
\hline No. & Title \\
\hline 1 & $\begin{array}{l}\text { Department of eLearning. (2015). 21st Century Competencies for Our Age: The } \\
\text { Digital Age (The Fundamental Building Blocks of Digital Literacy From } \\
\text { Enhancement to Transformation). Green Paper: Digital Literacy. }\end{array}$ \\
\hline 2 & $\begin{array}{l}\text { Karpati, A. (2011). Digital Literacy in Education. Policy Brief. Moscow: } \\
\text { UNESCO Institute. }\end{array}$ \\
\hline 3 & 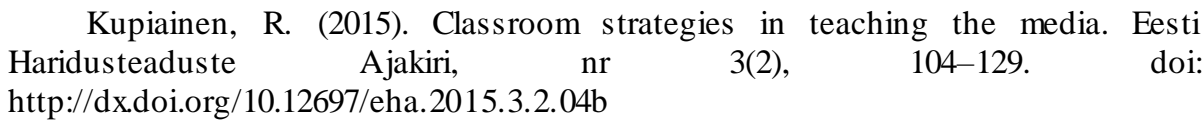 \\
\hline 4 & $\begin{array}{l}\text { Mutlu, A., \& Erŏz-Tuğa, B. (2013). The role of computer-assisted language } \\
\text { learning (CALL) in promoting learner autonomy. Egitim Arastirmalari-Eurasian } \\
\text { Journal of Educational Research, 51, 107-122. }\end{array}$ \\
\hline 5 & $\begin{array}{l}\text { Warschauer, M, Tate T, et. al.. (2014). Supporting Digital Literacy in } \\
\text { Educational Contexts: Emerging Pedagogies and Technologies. International } \\
\text { Baccalaureate Program. Irvine: University of California. }\end{array}$ \\
\hline
\end{tabular}

These references are based on the need of the topics. The content and vocabulary level are also considered. These references were expected to give supplementary materials to the students in understanding CALL and technology implementation, besides the materials provided online from the applications and websites.

\section{CALL Activities}

The activities in Computer Assisted Language Learning (CALL) course are based on the stated topics and objectives. They encourage future English teachers to review several applications and websites to be used in English teaching and learning, also, practice in designing CALL activities. How ever, the researcher found a discrepancy between syllabus and the practices in the classroom.

In the syllabus, students would learn the theories of CALL and technology-based English learning theories in the 1 st until the 7 th meeting. Then, they would have the practice after the midterm test in the 8 th until the 14 th meeting.

Whereas, in practice, students learned the theories of CALL in the first three meetings. After that, students needed to review individual applications or w ebsites to teach English. They worked collaboratively in group consists of 3-5 students. Several applications and websites under their review were Duolingo, FluentU, BBC Learning English, Canva, ABCYa.com, Manythings.org, British Coun cil, and Storynory. After reviewing it, they needed to present it in front of the class based on the sheet given by the teacher. The sheet consisted of general information (Name of app/site, Founder/developer, Country, Year found, Website address), features and affordances of the apps or sites, an example of classroom activities using the apps or sites.

After the mid-term test, students were free to choose applications/websites to design the classroom activities. They also could make it in accordance to the Junior High and Senior High syllabus. Students later needed to have simulation about the apps/sites to other friends in the classroom. There were two groups' presentation and simulation for each meeting. The lecturer termed this presentation and simulation as a w orkshop. Each w orkshop w as 30 minutes long. This w orkshop consisted of 3 parts: App introduction; Tour on the app; and Classroom learning demonstration using the app. The evaluation criteria are comprehension, interactivity, and confidence. So, primarily in this subject, students were prepared to have insight and ability to teach English using technology.

In selecting the applications, the lecturer said that he browsed to find the best. He explored several recommendations and tried it out by himself. He also thought of the features and affordances the applications offered to. He also got recommendation applications from iMOOC (Indonesian Massive Open Online Course) 2018. He was one of the instructors for that online course. iMOOC provides several mat erials for autonomous learning using technology. It gave several recommended apps and websites that can be 
used and tried to implement in the English classroom. The lecturer made use of the recommendation from iMOOC and decided eight applications/websites for this CALL course including Duolingo, FluentU, BBC Learning English, Canva, ABCYa.com, Manythings.org, British Council, and Storynory. They have different features and affordances so that in this case, future English teachers could explore it thoroughly .

From observation, the researcher found that interactive lecturing happened when theories of CALL were discussed. The lecturer showed the materials on the slide to the students, then discussing it with the students by having question and answer section. For the CALL activity design project, students w orked in a group. These were done outside the classroom. After that, they had to present it in front of the class. Microteaching was used in this activity. At the end of the presentation, the lecturer w ould give feedback to them.

\section{DISCUSSION}

The objective of a CALL course in this study is in line with Ghasemi and Hashemi (2011) that ICT training for teachers should not be merely to use technology per se. So that in this study, the objective of the CALL course is that university students are expected to do English teaching and learning using media and technology-based approach. It means that besides the future English teachers learn several applications and/websites, they also need to practice using those applications to teach the English language.

Then, the materials in this CALL courses answer the critic of several researchers that "university teacher preparation courses for putting more emphasis on a mastery of basic computer skills, such as using a particular software program, rather than on teaching students to integrate technology into their classroom teaching" (Han, et.al., 2013). The course gives materials about theories of CALL as well as the practice of CALL. It also includes lesson planning on how to teach English using certain applications or websites. It is also in line with Lee and Lee (2014, p. 127) that "through the lesson planning activities, the pre-service teachers were able to play an active role as designers of technology, relating technology to pedagogy and content".

The activities of CALL course also encourages future English teachers to work in a group and communicate with each other. It supports Hashemi and Aziznezhad (2011, p. 833) that "the CALL classroom should not be conceived as a room in which every learner is studying in isolation in front of his/her computer. Teachers must think of activities that enable group w ork/human interaction and computers to be compatible".

Further, from the result, the objective of CALL course, the materials delivered in the CALL course, and also classroom activities using CALL to teach English, can be an example for preparing future English teachers to teach technology, especially CALL. The design of a CALL course also can be the reflection for the lecturer to apply better CALL course design. For the future English teachers, this CALL course is expected to be a good experience in learning and teaching of technology, especially CALL. It is suggested for further research to explore more components of instructional design, such as syllabus model, assessment model, teacher's roles, and students' roles.

\section{CONCLUSIONS}

Instructional design of Computer Assisted Language Learning (CALL) course in Indonesian higher education for future English Teachers is essential to be explored further. This study shows the uniqueness of CALL course in one of Islamic University in Indonesia. The objective of CALL course, the materials delivered in the CALL course, and also classroom activities using CALL to teach English, can be an example for preparing future English teachers to teach technology, especially CALL. For future research, other instructional designs of a CALL course can be explored to give insight for a lecturer in teaching pre-service teachers. The current study was limited only on the objective of CALL course, the materials delivered in the CALL course, and also classroom activities using CALL to teach English. Also, the current study was from a single case of CALL course. For the next researchers who are interested in using computer assisted language learning (CALL) to teach English, it is recommended to explore more about the instructional design of CALL and more participant in wider context.

\section{ACKNOWLEDGMENTS}

The authors would like to express thanks for the special honor to Endowment Fund for Education (LPDP Republic of Indonesia, Ministry of Finances) that gives financial support and sponsor. 
Azmina,B., Fauziati,E.\& Drajati,N.A. (2019). Instructional design of CALL course in Indonesian higher education for future english teachers: A case study .International Journal of Educational Research Review, 4(2),223-230.

\section{REFERENCES}

Berge, Z.L. (1996). The role of the online instructor/facilitator. http://www. emoderators.com/moderators/teach_online.html.

Cameron, K. (1999) Introduction. In K. Cameron (ed.), CALL: media, and applications (pp. 1-10). Lisse: Swets \& Zeitlinger.

Egbert, J. \& Hanson-Smith, E.(1999). Computer assisted language learning: Research, practice, and critical issues. Alexandria, VA: TESOL.

Fauziati, E. (2016). Applied Linguistics: Principles of Foreign Language Teaching, Learning, and Researching. Surakarta: Era Pustaka Utama.

Ghasemi, B., \& Hashemi, M. (2011). ICT: Neww ave in English language learning/teaching. Procedia - Social and Behavioral Sciences, 15, pp. 3098-3102. https://doi.org/10.1016/j.sbspro.2011.04.252

Han, I., Eom, M., \& Sug, W. (2013). Multimedia case-based learning to enhance pre-service teachers' knowledge integration for teaching with technologies. Teaching and Teacher Education, 34, pp. 122129. https://doi.org/10.1016/j.tate.2013.03.006

Hashemi, M., \& Aziznezhad, M. (2011). Computer assisted language learning freedom or submission to machines? Procedia - Social and Behavioral Sciences, 28, pp. 832-835. https://doi.org/10.1016/j.sbspro.2011.11.152

Jack C. R. \& Rodgers T. S. (2001). Approaches and methods in language teaching, United. States: Cambridge University Press.

Katic, E. K. (2008). Preservice teachers' conceptions about computers: An ongoing search for transformative appropriations of modern technologies. Teachers and Teaching: Theory and Practice, 14 (4), pp. 157179.

Lee, Y., \& Lee, J. (2014). Computers \& Education enhancing pre-service teachers ' self-efficacy beliefs for technology integration through lesson planning practice. Computers \& Education, 73, pp. 121-128. https://doi.org/10.1016/j.compedu.2014.01.001

Levy, M. (1997). Computer-assisted language learning: Context and Conceptualization. Oxford University Press.

McArdle, F. (2010). Preparing quality teachers: Making learning visible. Australian Journal Of Teacher Education, 35(8). http://dx.doi.org/10.14221/ajte.2010v35n8.5

Miles, M. B., \& Huberman, A. M. (1994). Qualitative data analysis an expanded sourcebook. Thousand Oaks, CA Sage Publications.

Papadima-sophocleous, S. (2012). CALL (computer-assisted language learning) wiki, 34, 174-180. https://doi.org/10.1016/j.sbspro.2012.02.035

Queiroz, V. 2003 Roles, and competencies of online teachers. The Internet TESL Journal, 9(7). http://iteslj.org/Articles/Queiroz- OnlineTeachers.html. (14 November 2005).

Richards, J. (2001). The role and design of instructional materials. In Curriculum Development in Language Teaching (Cambridge Language Education, pp. 251-285). Cambridge: Cambridge University Press. doi:10.1017/СBO9780511667220.010

Simon, E. (2008). Foreign language faculty in the age of web 2.0. EDUCAUSE Quarterly, 31(3). Retrieved from http://www .educause.edu/EDUCAUSE+Quarterly/EQVolume312008/EDUCAUSEQuarterlyMagaz ineVolum/163109

Soulsby, E. P. (2009). Assessment notes [Online] Available: http://assessment.uconn.edu/docs/resources/Eric_Soulsby_Assessment_Notes.pdf [March, 2015].

Stake, R. (1995). The art of case study research (pp. 49-68). Thousand Oaks, CA: Sage. 
Azmina,B., Fauziati,E.\& Drajati,N.A. (2019). Instructional design of CALL course in Indonesian higher education for future english teachers: A case study .International Journal of Educational Research Review, 4(2),223-230.

Warschauer, M. \& Healey, D. (1998). Computers and language learning: An overview . Language Teaching, 31, pp. 57-71

Zhang, J. (2014). Task-Oriented Internet Assisted English Teaching and Learning in Colleges, 9(12), pp. 14-32. https://doi.org/10.4018/ijwltt.2014100102 